\title{
Enterovirus infections and type 1 diabetes mellitus: is there any relationship?
}

Tavares RG (1, 2), Trevisol RB (3), Comerlato J (3), Dalzochio T (3), Feksa LR (2), Spilki FR (2), Berlese DB (2)

(1) Department of Diagnostic Methods, Federal University of Health Sciences of Porto Alegre, Porto Alegre, Rio Grande do Sul State, Brazil; (2) Health Sciences Institute, Feevale University, Novo Hamburgo, Rio Grande do Sul State, Brazil; (3) Undergraduate Program in Biomedicine, Feevale University, Novo Hamburgo, Rio Grande do Sul State, Brazil.

\begin{abstract}
Several health organizations have classified diabetes mellitus, a metabolic syndrome, as the epidemic of the century, since it affects millions of people worldwide and is one of the top ten causes of death. Type 1 diabetes is considered to be an autoimmune disease, in which autoaggressive T cells infiltrate the islets of Langerhans in the pancreas, leading to the destruction of insulin producing beta cells. The risk of the disease is modulated by genetic factors, mainly genes coding for human leukocyte antigens (HLA). However, the incidence of this disease has increased significantly during the recent decades, which cannot be explained only by genetic factors. Environmental perturbations have also been associated to the development of diabetes. Among these factors, viral triggers have been implicated; particularly enteroviruses, which have been associated to the induction of the disease. Supporting the hypothesis, numerous lines of evidence coming from mouse models and patients with this type of diabetes have shown the association. The present review aims to provide some understanding of how type 1 diabetes occurs and the possible role of enterovirus in this pathology.
\end{abstract}

Key words: diabetes mellitus type I, enterovirus, autoimmune disease.

\section{INTRODUCTION}

According to the World Health Organization (WHO), diabetes is a condition primarily defined by the level of hyperglycemia that raises the risk of microvascular damage including retinopathy, nephropathy and neurophathy (1). Our knowledge on diabetes mellitus has been developed over centuries. The first descriptions of studies with diabetic patients appeared during the last century, but the disease began to attract greater attention from 1920 onwards, when pathologies associated with diabetes began to be discovered.

Diabetes is caused by the failure to produce insulin and by a reduction in the sensitivity of tissues to insulin. Therefore, it affects the metabolism of all types of nutrients, since insulin is essential for the metabolism of carbohydrates, proteins and lipids.

Over recent decades, the proportion of nontransmissible diseases has increased (2). Among such diseases, diabetes (types I and II) is one of the top ten causes of death (3). By 2004 it was estimated that there were 171 million people in the world with diabetes in that year and this number was predicted to increase to 366 million by 2030 (4).

\section{TYPE 1 DIABETES MELLITUS}

Type 1 diabetes mellitus (T1D) is the result of a reduction or absence of insulin production caused by the destruction of pancreatic $\beta$ cells. Viral infections or autoimmune disorders can be involved in $\beta$ cell destruction, but heredity also 
plays an important role in defining susceptibility to the destruction caused by these factors. In contrast to $\mathrm{T} 1 \mathrm{D}$, type 2 diabetes is a nonautoimmune mediated disease, which results from a combination of insulin resistance and lack of pancreatic $\beta$ cells to compensate this insensitivity (5).

Diabetes mellitus is a chronic disease. There is no cure with conventional methods, so clinical management of glucose levels in blood and tissues is the therapy of choice. Moreover, treatment involves dietary and lifestyle changes, engagement in physical activities and, primarily, insulin administration considering glycemic assays. Therefore, smokers, sedentary and obese individuals have a poor prognosis as diabetic patients (6).

Patients with T1D might present hypertriglyceridemia (chylomicrons and VLDL) and suffer episodes of severe ketoacidosis, which leads to increased lypolisis in adipose tissues and accelerated oxidation of fatty acids in the liver. Hyperchylomicronemia suppresses the activity of lipoprotein lipase, an enzyme whose synthesis is dependent on insulin, in adipose tissue capillaries (7). Although insulin does not cure T1D, it does significantly modify the disease's clinical course by promoting glucose uptake and inhibiting gluconeogenesis, lypolisis and proteolysis (7).

If patients remain untreated, they may suffer both microvascular and macrovascular complications that increase morbidity and mortality (8). Microvascular complications include nephropathy, retinopathy and neuropathy, whereas progression to macrovascular problems primarily leads to heart diseases (9).

\section{T1D EPIDEMIOLOGY}

Data from WHO-sponsored Diabetes Mondiale (DIAMOND) study indicate that T1D incidence varies widely among and within countries (10). Populations in Africa, Asia and Central and South America have relatively low rates of T1D. Countries in Northern Europe, North America, New Zealand and Australia have the highest rates $(10,11)$. An understanding about the differences between these data would be useful to guide prevention efforts.

Incidence rates also reveal geographic differences between Northern and Southern hemispheres. The reason for the observed variations in T1D incidence is unclear, but differences in diet, lifestyle, and/or genetics may be involved (11-13).

According to the Brazilian Ministry of Health, more than 6 million people in the country were diagnosed with diabetes (14). On this basis, the mean prevalence in the adult population is $5.2 \%(3,4,14)$. However, it is estimated that approximately $50 \%$ of the individuals with the disease have not been diagnosed (3). In contrast with other autoimmune diseases that affect females more than males, the incidence of diabetes is higher in males, particularly between 25 and 29 years $(15,16)$.

Data from a wide range of studies by several authors show that T1D rates are higher in more industrialized countries with higher standards of living than in less developed countries with lower standards of living, which has led to the hygiene hypothesis. This hypothesis suggests that reduced exposure to infections resulting in less protection from infectious agents is one of the causes for the increased incidence of T1D in the most developed countries $(17,18)$. Retrospective studies suggest that T1D patients have been exposed to a reduced number of infections, which could support this hypothesis $(19,20)$.

\section{GENETIC FACTORS INVOLVED IN T1D}

Several different mechanisms are associated with the emergence of T1D and these mechanisms may or may not be related to one another. Genetic susceptibility is believed to be one determinant factor in the development of the disease (21-23).

The risk of a member of the general population to develop T1D is often quoted as $0.4 \%$. This increases to $>1 \%$ if the mother has diabetes and intriguingly to $>3 \%$ if the father has T1D (24). The sibling risk is $6 \%$ (15 times greater than in a member of the general population) (25).

Studies performed with homozygous twins have demonstrated that the concordance rate to develop T1D is $27-40 \%$, whereas for heterozygous twins the figure drops to $4-7 \%(5,26,27)$. Furthermore, the frequency of diabetic patients is higher in close relatives of diabetic subjects than in general (nondiabetic) population (5).

The most important genetic influence comes from an allele polymorphism in the human leukocyte antigen (HLA), located on the short arm of chromosome 6 (6p21.3) (27). This 
polymorphism can lead to functional differences in how fragments of protein are presented to the immune system (28). This predisposition accounts for 40 to $50 \%$ of the genetic risk $(29,30)$.

Another gene associated with T1D is located on chromosome $2 \mathrm{q} 33$. This gene is responsible for the production of cytotoxic $\mathrm{T}$ lymphocyte antigen (CTLA-4), which is a molecule found in $\mathrm{T}$ cells that produces a negative signal for $\mathrm{T}$ cell activation (11). However, the increase of T1D in most population cannot be explained only by genetic modifications (23).

\section{ENVIRONMENTAL AGENTS INVOLVED IN T1D}

In combination with genetic predispositions, environmental factors have great impact on the emergence and progression of T1D. The autoimmune etiology of T1D has been studied in recent years, but how environmental factors influence the pathology is still unclear. Elucidation of these characteristics could represent an important step in the development of treatment or in improvement of patients' quality of life.

T1D cases are increasing from 3 to $5 \%$ everyyear along with its prevalence rates worldwide, which may give an idea of the effects of environmental factors on its emergence, since factors such as genetic mutations among populations could not cause such significant increases (31).

On a smaller scale, studies are also being conducted involving bacterial infections that cause autoimmune diseases such as T1D. Their effect on antibodies against pancreatic $\beta$ cells is similar to the mechanism observed in viral infections (32).

It has been postulated that the consumption of cow's milk by infants too early influences the triggering of autoimmune diseases, such T1D (33). However, some authors suggest that a short duration of breastfeeding before switching to cow's milk does not actually increase the risk of development of the disease $(34,35)$. Thus, these hypotheses have been the subject of much investigation and remain unproven, but not denied (36).

Increased intake of vitamins - mainly C, D and $\mathrm{E}$ - has been associated with a reduction in islet autoimmunity. In contrast, early substitution of breast milk for cereals, food containing nitrosamine compounds - produced from nitrites and amines - and some types of fruit may increase the chance of developing islet autoimmunity (37).

Experiments using vitamin D or one of its analogues showed that they were capable of preventing the development of T1D in animal models. In humans, vitamin D supplementation during childhood is associated with a reduced risk of developing the disease (38).

Associations between viral infections and T1D have been described since the 1970s and some theories on their pathogenic effects have been proposed. One example is the hypothesis of direct infection and lysis of pancreatic $\beta$ cells, but numerous authors have found it hard to identify evidence of viral activity in these cells (31). This difficulty could be the result of a large number of viruses involved and the mechanisms by which they act.

The role of several viruses such as rotavirus, adenovirus, retrovirus, reovirus, cytomegalovirus (CMV), Epstein-Barr virus, mumps virus, or rubella virus in the pathogenesis of T1D was hypothesized (32, 33, 39-46). However, enteroviruses, especially coxsackievirus $\mathrm{B}$, are among the viruses more likely to be involved in the pathogenesis of the disease $(46,47)$.

Table 1 lists the main viruses that have been implicated as possible causes of T1D and the mechanisms of action that are involved in the cell death.

\section{ENTEROVIRUS (EV)}

Recent studies have focused on infection by EV, which is the most common type of viral infection in humans and increases the risk of development of T1D. Papers published prior to 1970 were already describing this relationship (48).

The Enterovirus genus belongs to the Picornaviridae family, which is subdivided into twelve genera: Aphthovirus, Avihepatovirus, Cardiovirus, Enterovirus, Erbovirus, Hepatovirus, Kobuvirus, Parechovirus, Sapelovirus, Senecavirus, Teschovirus and Tremovirus (49)

The Picornaviridae family is one of the largest and most important families of viruses both from the perspective of human health and for farming. The family includes virus groups that have pathogenic activity. As its name suggests (pico = very small), this family contains some of the smallest known microorganisms (50). 
Table 1. Main viruses that might cause T1D and their mechanisms of action

\begin{tabular}{|c|c|}
\hline Virus & Effects on cells \\
\hline Enterovirus & $\begin{array}{l}\text { Induction of autoantibodies, induction of } \beta \text { cell lysis, molecular mimicry, } \\
\text { stimulation of autoreactive T-cell activity. }\end{array}$ \\
\hline Cytomegalovirus & $\begin{array}{l}\text { Infection of } \beta \text { cells, clonal activation of T cells, induction in macrophage } \\
\text { recruitment to the pancreas. }\end{array}$ \\
\hline Rotavirus & Infection of $\beta$ cells, molecular mimicry. \\
\hline \multirow{2}{*}{ Rubella virus } & $\begin{array}{c}\text { Induction of cross-reactions between viral antigens and GAD, which are } \\
\text { then subject to T lymphocyte activity }\end{array}$ \\
\hline & infection of $\beta$ cells. \\
\hline Mumps virus & Infection of $\beta$ cells, increased expression of HLA classes I and II in $\beta$ cells. \\
\hline Parvovirus & $\begin{array}{c}\text { Does not infect } \beta \text { cells, macrophages activate a type Th1 immune response } \\
\text { cascade while type Th } 2 \text { response is attenuated. }\end{array}$ \\
\hline
\end{tabular}

These viruses have a non-enveloped structure with an icosahedral capsid of approximately 27$30 \mathrm{~nm}$ in diameter that contains the proteins VP1, VP2, VP3 and VP4, which are involved in the viral infection process. VP1 is a more superficial protein and is predominantly exposed, while VP4 is more internal and is associated with nucleic acid (51).

These proteins that constitute the viral capsid perform the following functions: they protect the viral genetic material from the nucleases of the host cell's cytoplasm, they recognize specific receptors in the host cell membrane, they organize the viral genome and they play a role in penetration of the plasmatic membrane and liberation of the genetic material (50). The same proteins are also responsible for the virus resistance in the environment.

The picornavirus genome is encoded as a single-stranded positive-sense RNA of 75008000 bases that comprises an open reading frame flanked by 5' and 3' untranslated regions (52).

The name EV derives from the fact that these viruses replicate in the gastrointestinal tract and are primarily released into the environment in fecal material. They are common in many animals, including humans, cattle, pigs and mice (20). Enteroviruses are transmitted mainly through the fecal-oral or respiratory routes and the transmission depends on socioeconomic factors such as crowding and standard of hygiene $(53,54)$. Furthermore, some authors have also described cases of contamination from secretions from the eyes and skin (55). These pathogens can be classified as enteric, since they are excreted in feces, and they are also frequently found in contaminated water (56).

\section{EPIDEMIOLOGY OF ENTEROVIRAL INFECTIONS}

Enteroviruses are the viral agents most commonly found causing disease in humans. Infections have seasonal distribution, and are more frequent during summer and spring (50, 57). However, neonatal infections, despite being common, exhibit less seasonal variation (57).

It is estimated that there are approximately 10 to 15 million symptomatic infections caused by enteroviruses in the United States every year (58). One study reported that $51,3 \%$ of fecal samples from healthy Norwegian children were positive for the virus, of which species A was the most frequently detected (59).

The prevalence of different serotypes follows a geographic distribution. Research conducted in London identified infection in $5.4 \%$ and $1.2 \%$ of tests for species A and B respectively. In Australia, $12.1 \%$ were positive for $\mathrm{A}$ and $4.3 \%$ for species B. These findings are compatible with prevalence rates reported by other authors globally (15).

Data indicate that in some countries, such as France, most cases of EV infection are in children and one third of them are in children less than 1 year old $(57,58)$. Studies conducted by the Centers for Disease Control and Prevention (CDC), in the United States, indicate that 10\% of the total number of $\mathrm{EV}$ infection cases in the country are in neonates (57). 
Differences among populations in different countries may be associated with quality of life, sanitary conditions, the quality of health services, and so forth.

\section{ENTEROVIRUS BIOSYNTHESIS}

In this virus family, the entire biosynthesis process occurs within the cytoplasm of the host cell. The viral RNA is translated into a polyprotein which then cleaves, giving rise to several products including the four structural proteins VP1 through VP4 (50).

The process begins with adsorption of the virus by specific receptors on the host cell. Viral genetic material is then released into the cytoplasm under VP4 activity. The RNA molecule induces production of polyproteins in the host cell ribosome, giving rise to new RNA molecules and RNA polymerase which, in turn, produce more viral proteins (50).

The search for effective vaccines, especially against foot-and-mouth disease and poliomyelitis, led to the discovery of a series of other similar viruses. New EV serotypes have been described recently, and more than 100 species have been recorded.

The current International Committee on Taxonomy of Viruses classification divides the genus into ten species. Seven of these can be isolated in humans: human rhinoviruses A, B and $\mathrm{C}$ and human enteroviruses $\mathrm{A}$ to $\mathrm{D}$. Three of them can be detected in animals: bovine enterovirus, simian enterovirus $\mathrm{A}$ and porcine enterovirus $\mathrm{B}$ (49).

\section{VIRAL RESISTANCE AND ENVIRONMENTAL CONTAMINATION}

Most enteroviruses are stable in mediums with $\mathrm{pH}$ from 3 to 9 . They can be resistant to chemotherapy, to antibiotics, to $70 \%$ alcohol and to some detergents. They are, however, thermolabile and are destroyed if exposed to temperatures above $50^{\circ} \mathrm{C}$ (50). Moreover, they are resistant to chlorine compounds normally used in water treatment systems and to large temperature changes. These characteristics mean that, in addition to water, these viruses can also contaminate food and the soil.

According to the Brazilian Ministry of Health's directive number 518 of 2004 , water potability tests must take total coliform bacterial counts into consideration, in addition to other parameters such as ions, turbidity, $\mathrm{pH}$, acidity and alkalinity (14). The term "coliform" habitually refers to Escherichia coli and other species belonging to other genera in the Enterobacteriaceae family. A wide swath of microorganisms is not detected by coliform tests, including other bacteria that are enteropathogenic to humans, enteroviruses and other enteric virus (60).

Some studies have reported EV contamination of potable water used for drinking, for food preparation and washing, which could be a significant vector for virus transmission, since the risk of infection after ingestion of contaminated water is 10 to 10,000 times greater than the risk of bacterial infection (60).

WHO considers that contamination of water with EV is an extremely serious problem and a possible cause of epidemics (1). Several authors have identified EV as the agent of foodborne diseases that affect millions of people worldwide (60).

The resistance properties of enteroviruses and their wide geographic distribution, in addition to the effects that they have on the development of T1D, emphasize that further studies are required to provide a basis for policies to prevent their transmission.

\section{CLINICAL FEATURES OF EV INFECTIONS}

The discovery of new methods to identify enteroviruses, whether by their RNA or by the antibodies produced against them, has meant that studies considering the relationship between these viruses and T1D are now reporting good results (32). The possibility of isolating enteroviruses - primarily coxsackieviruses - in $\beta$ cells from diabetic patients may represent a direct evidence of the relationship between them.

In general, the influence of viruses on T1D may affect the initial events of the disease and/or be a triggering factor in susceptible individuals. The connection between chronic or reactivated $\mathrm{EV}$ infections and the development of autoimmune disorders, such as T1D, has been shown in several studies (49, 61-63). One of the greatest difficulties involved when attempting to trace associations between these events is the fact that EV has a wide distribution and causes a variety of pathologies. 
The incubation period generally ranges from 7 to 14 days, but it can reach extremes of 4 to 30 days. After the initial multiplication, which primarily occurs in lymphoid tissues, viremia begins and the virus will then proliferate through the cells of the reticuloendothelial system and, finally, attack specific organs such as the heart, skin, central nervous system and $\beta$ cells in the pancreas (50, 64-66). Most infections caused by EV (around 90\%) progress asymptomatically.

\section{ENTEROVIRUS ACTIVITY AND IMMUNOPATHOGENESIS INVOLVED IN T1D}

Susceptible cells that become EV hosts provide it with energy and the precursors needed to synthesize the component parts of the virus as well as structures required to synthesize proteins, such as ribosomes, transfer RNA and enzymes. The result is a series of drastic alterations in cell metabolism. The majority of infections cause morphological changes in infected cells including chromatin marginalization, through which the nuclear material loses its characteristic homogeneity (50). It has been shown that enteroviral infections can lead to production of RNA molecules inside the infected cell (67). Around three hours after infection, membranous vesicles appear in the cytoplasm, changing cell permeability and causing loss of intracellular material and, later, cell death (50).

Studies that investigated children at risk of developing T1D found that there was a greater prevalence of EV infections in the subset that later developed autoantibodies than among children who did not develop these antibodies (41).

Histological analysis of pancreas from patients with recent-onset T1D revealed an infiltration of mononuclear cells - such as B and T lymphocytes, monocytes and natural killer cells - into the islets of Langerhans (68-70). Furthermore, some viruses exhibit tropism towards pancreatic $\beta$ cells, demonstrated by detection of viral RNA. Both detection of the infection and its pathogenesis are related to the viral load. By the time clinical symptoms including polyuria and ketonemia appear, approximately 60 to $80 \%$ of the $\beta$ cells must already have been destroyed (71). Other islet cells that secrete glucagon, somatostatin and pancreatic polypeptide are generally spared during the autoimmune attack against the $\beta$ cells (5).
Several studies have demonstrated that EV infections, during which IgM and IgG antibodies are produced against the infectious agent, precede the appearance of autoimmune mechanisms, with the first signs appearing within the first 3 to 6 months after infection. During this period, antibodies may be produced against $\beta$ cells, insulin, GAD or tyrosine-phosphatase (IA2) (68). In recent years, the presence of antibodies against zinc transporter 8 (ZnT8) has also been linked to T1D (72).

Glutamic acid decarboxylase catalyzes decarboxylation of glutamic acid to synthesize gamma aminobutyric acid, which acts as an inhibitory neurotransmitter. Two distinct forms of GAD have been identified and found to be encoded by two different genes (73). GAD is expressed not only in the pancreatic islet, but also in central and peripheral systems, testes, ovaries, thymus and stomach (74-77).

A T-cell-mediated autoimmune response destroys pancreatic $\beta$ cells, leading to reduction and progressive loss of insulin production (78). Proliferation of $\mathrm{T}$ cells in response to the viral infection has been described and linked to cases of T1D, primarily affecting children (79). This association is not only influenced by the heightened production of cells, but also by the activity of these cells that produce cytokines (68, 79).

The presence of autoantibodies against $\beta$ cells is a reliable predictive marker for the development of T1D and identification of autoantigens could be used in the development of treatment interventions that modulate the immune response to these antigens (8).

The most potent antiviral cytokines involved in infectious processes are type 1 interferons, including interferon $\alpha$ and $\beta$. They are part of the innate immune system which is early activated during an infection before adaptive immune responses are induced (41).

During the anti-inflammatory response, even at low viral concentrations, three cytotoxic substances are produced including interleukin (IL)-1 $\beta$, tumor necrosis factor (TNF)- $\alpha$, interferon (IFN)- $\alpha$ and free radicals, such as nitric oxide, which are toxic to $\beta$ cells and contribute to progression of cell damage (80-82).

Patients recently diagnosed with T1D have increased production of IFN- $\gamma-$ a proinflammatory cytokine generated by $\mathrm{CD} 4$ 
memory cells - and reduced $\mathrm{T}$ cell proliferation $(68,83)$.

There is not a consensus on the process by which enteroviruses induce destruction of $\beta$ cells yet, but the main possibilities are: through polyclonal activation of lymphocytes by the infection, through production of protein sequences by the pathogen that mimic autoantigens, and through induction of anti-inflammatory responses in the host organism (32). Molecular mimicry is heavily involved in development of autoimmune diseases in the presence of infectious processes. Molecular mimicry processes may be involved in the form of cross-reactions in which antibodies against viral antigens attack the pancreatic islet cells $(68,84)$.

In the case of $\mathrm{T} 1 \mathrm{D}$, this mechanism may be invoked if a T-cell epitope from an infectious agent activates autoreactive $\mathrm{T}$ cells which recognize autoantigen epitopes with a similar or identical peptide sequence. Similarity between peptides may therefore be a determinant factor in the mimicry mechanism, triggering the crossreactions that are involved in autoimmune diseases (68).

$\mathrm{T}$ cells have the potential to interact with thousands of peptides and MHC complex molecules. Regarding the fact that adults have millions of these cells, millions more T-cell receptors can be generated by rearrangement and substitution of the genes for these cells, with the production of T-cell clones (68).

The HLA region codes for proteins that are expressed on the surface of cells. Class I region codes for transplantation antigens HLA-A, HLA-B and HLA-C, which are involved in presentation of antigens to CD8+ (cytotoxic) T cells. Class II region encodes the $\alpha$ and $\beta$ chains of HLA-DR regions, formerly known as the immune response genes, which are involved in presentation of antigen peptides to the T-cell receptor on $\mathrm{CD} 4+$ (helper) T cells $(85,86)$.

The discovery of the existence of six amino acid sequences that are identical to a nonstructural EV protein (P2C) and the GAD-65 autoantigen may lead to a better understanding of the development of T1D and guide us towards the possible existence of mimetic epitopes combined with HLA molecules causing T1D. In common with the $\mathrm{P} 2 \mathrm{C}$ protein, the VP1-VP5 proteins in the capsid of EV are also targeted by T cells and may be important agents of molecular mimicry (68).
Many different possible cross-reactions involving proteins, epitopes and autoantigens have been suggested, but to describe them would require greater depth of detail than the scope of this article allows.

During an enterovirus infection, an inflammatory process occurs in the pancreas provoking tissue damage and the release of autoantigens; concomitantly autoreactive $\mathrm{T}$ cells are also activated by proinflammatory cytokine production. For this phenomenon to occur there must be an accumulation of $\mathrm{T}$ cells in the organ (68). This mechanism is known as bystander activation.

After $\beta$ cells have been infected, viral replication occurs inside them. The replication process is associated with chronic INF- $\alpha$ production by the pancreatic cells. It has been suggested that INF- $\alpha$ is a mechanism for defense against cell destruction. In addition to this antiviral effect, INF- $\alpha$ serves as a regulatory mechanism between the innate and adaptive immune systems, regulating gene expression of cytokines and their receptors. The primary source of INF- $\alpha$ is the dendritic cells, which, in turn, stimulate a response from $\mathrm{T}$ cells, when activated $(32,68)$.

Type I interferons are able to induce an antiviral cell state that provide a line of defense against infectious agents. Experiments have determined that these interferons act in order to reduce the permissiveness of $\beta$ cells to viral infection and that such permissiveness may regulate susceptibility to the development of T1D (32).

Table 2 lists the mechanisms that are possibly involved in the development of T1D.

\section{ENTEROVIRUS ACTIVITY IN ANIMAL MODELS}

Animal models offer an extremely useful method to study the possible pathogenic and immunological mechanisms of T1D, since the results afford an opportunity to understand the disease. However, there are certain differences related to the immune response in humans. One example is the effect of cytokines produced by macrophages that infiltrate the pancreatic $\beta$ cells. Human $\beta$ cells seem to be more resistant to the necrosis caused by these cytokines than animal cells $(78,87)$.

There is an important relationship between susceptibility genes and T1D, but studies on 
Table 2. Immune mechanisms that are possibly involved in the development of T1D

\begin{tabular}{c|c}
\hline Mechanism & Possible effect \\
\hline Molecular mimicry & $\begin{array}{c}\text { Similarities between amino acids in the virus and in cellular antigens induce } \\
\text { the host into cross-reactions by which antibodies are activated and attack } \\
\text { the pancreatic islet cells. }\end{array}$ \\
\hline $\begin{array}{c}\text { Activation of } \\
\text { autoreactive T } \\
\text { lymphocytes }\end{array}$ & $\begin{array}{c}\text { During the inflammatory process large numbers of Tells and antigens are } \\
\text { taken up, triggering a chain reaction in which cytokines are released and } \\
\text { more T cells migrate. }\end{array}$ \\
\hline Cytokines & $\begin{array}{r}\text { Viral infection, cell lysis and viral replication processes induce the release of } \\
\text { cytokines that activate immunological responses. }\end{array}$ \\
\hline Superantigens & T cells that infiltrate pancreatic cells that may exhibit certain T-cell receptor \\
expansions and act as superantigens
\end{tabular}

animal models - in which twins are subjected to different environmental factors - only detected a $40 \%$ correlation (26). EV infections in animal models also exhibit T-cell destruction mechanisms seen in humans, including GAD, IA2 and insulin (88).

Approximately $60 \%$ of samples of Biobreeding rats and non-obese diabetic mice developed T1D (30). The onset was between 60 and 120 days of age approximately and was associated with a massive influx of CD4+ T lymphocytes, CD8+ T lymphocytes and macrophages into the $\beta$ cells. The behavior of cells in terms of cytokine release is the same for males and females and even animals that did not develop T1D exhibited lymphocyte infiltration and $\beta$ cell destruction $(78,87)$.

Previous studies have shown that when a specific diabetes-susceptible strain of rat was inoculated with high titers of encefalomiocarditis virus, it developed an infection which led to T1D within three days. This probably occurred due to the rapid destruction of $\beta$ cells during viral replication in the cells before the induction of sufficient neutralizing antibodies against this virus (89).

\section{STUDIES IN HUMANS}

Although several studies have been performed in animals in order to show the possible role of EV in triggering T1D, some studies in humans can also demonstrate such relationship. Evidence of the role of EV in the development of T1D was first obtained in studies showing increased prevalence of enteroviral RNA in sera of recent-onset T1D patients compared with healthy controls $(90,91)$. Since then, several authors have been reporting such connection.

Higher rates of EV infection - defined by the detection of EV IgM or IgG (or both), and viral RNA by polymerase chain reaction (PCR), and viral capsid protein - have been found in patients with diabetes at diagnosis compared with controls (67, 91-96).

One of these studies reported the high prevalence of EV variants in the serum of children at the onset of T1D. Serum samples of 110 diabetic children were tested for the presence of enterovirus sequences by PCR. A control of 182 children was used, which was matched for age, geographic location and time of the year. A significantly greater number of diabetic children ( $27 \%$ vs. $4.9 \%$ ) had evidence of enterovirus RNA sequences (93).

A proportion of patients with $\mathrm{T} 1 \mathrm{D}$ was shown to have an ongoing EV infection in gut mucosa. This was demonstrated by a study that detected EV by in situ hybridization and immunohistochemistry. EV was detected by in situ hybridization in $50 \%$ of the patients with T1D, while in none of the control subjects. Immunohistochemistry identified EV in $75 \%$ of the patients and only in $10 \%$ of control subjects (97).

Prospective studies have also shown more $\mathrm{EV}$ infections in children who developed islet autoantibodies or subsequent diabetes, or both; as well as a temporal relation between infection and autoimmunity $(94,98,99)$.

Nevertheless, this relationship has not been consistent across all studies (100-102). Therefore, more extensive studies are required to further investigate the role of these viruses, and other environmental factors, in T1D. 


\section{IN VITRO STUDIES OF EV}

In vitro models have shown that cell apoptosis and necrosis may induce immune responses. Cultures of dendritic cells and cells that suffer apoptosis exhibit production of antigens and subsequent stimulation of MHC $\mathrm{T}$ cells. Macrophages subjected to similar conditions also secrete cytokines involved in inflammatory processes (87).

While several studies have been successful using cell cultures and have isolated cytokines such as TNF- $\alpha$, IL- $\beta$ and other radicals, the truth is that gaining an understanding of the processes involved in T1D using these research methods is still greatly hampered by the large number of different agents that are active in each case (31, $78,87)$.

\section{MONITORING OF MOTHERS AND THEIR CHILDREN}

Some studies have further suggested that maternal EV infection during pregnancy could increase the risk for T1D in the offspring $(98,99$, $103,104)$.

Exposure to environmental risk factors during the prenatal and postnatal periods has been shown to be significantly related to development of T1D. Among these factors, advanced maternal age at pregnancy, complications during delivery pre-eclampsia and mother-child blood-group incompatibility can be listed (105).

Studies have detected antibodies against enteroviruses in the mothers of diabetic children, particularly, coxsackievirus and echovirus (103, 106, 107). Furthermore, an increased prevalence of enterovirus RNA has been found in neonates who developed T1D later in life compared to subjects who did not develop the disease (108).

In a study, a given serotype was isolated from the rectal tract of a neonate and it was found to be the same type identified in the mother, supporting the vertical transmission hypothesis (57). Other samples from which matching serotypes have been identified are the amniotic fluid and umbilical cord $(57,87)$.

On the other hand, perhaps the high rate of infection with enteroviruses among newly diagnosed diabetic patients merely reflects an increased susceptibility of such patients to infective processes, since they exhibit tropism for $\beta$ cells, which are already damaged $(41,57)$.

$\mathrm{EV}$ infections may cause sporadic transmission in neonates in hospitals. In such cases, the transmission was the result of patient handling by physicians, nurses and other workers (57).

\section{DIAGNOSIS OF VIRUSES AND ENTEROVIRUSES}

Specific diagnosis of EV infections demands detection in samples collected from the patient, since clinical signs are not sufficiently specific because of the diversity of host responses and the large number of different serotypes. Diagnosis involves both clinical and epidemiological features. The main methods used to detect these viruses are: viral culture, immunofluorescence, serology and amplification of genetic material.

Isolation of viruses in cell cultures can be used to diagnose infection. Samples may be taken from the oropharynx, blood, cerebrospinal fluid or urine, among other tissues. Enteroviruses grow rapidly in cell cultures, when compared to other viruses, taking from 4 to 8 days, but even so the results are not available early enough to aid in treating patients. The main limitations of viral isolation in cell culture are its low sensitivity and the need to identify different serotypes (58).

Serology-based detection techniques also present certain limitations, since it is necessary to make a distinction between acute and chronic infections. The method is basically based on the immunological antibody-antigen reaction. Since there are such a large number of serotypes, serological methods are not routinely used for $\mathrm{EV}$ diagnosis in the laboratories unless there is a need to test for a specific serotype (50).

The use of PCR enabled viruses to be identified by molecular methods, thus circumventing the indirect approach through antibody based methods (41). In addition to requiring very little sample material, results can be obtained in 24 hours. These tests are more appropriate in order to identify recent infections, since detection is directly linked to viral load. Furthermore, their high sensitivity and specificity make this the most appropriate method to use in investigations.

Using two techniques in combination might be a good option to identify EV and to associate it with the development of T1D, particularly in children (15).

With the advent of molecular techniques, 
identification has become easier, which has helped both patient diagnosis and epidemiological studies.

\section{CONCLUSIONS}

Type 1 diabetes mellitus is a public health problem that affects general population and burdens health systems, which expend huge resources on attempting to maintain patients' quality of life.

In many countries, the prevalence of diabetes mellitus has augmented significantly and the increases are expected to continue. In developing countries, there is a tendency to raise its frequency in all age groups, especially among the young people, for whom the negative impact on quality of life and the resulting burden on health systems are immeasurable.

The identification of biomarkers which indicate that metabolic syndromes like T1D are emerging might be a significant aid in choosing the correct form of patient management. The possibility of identifying a disease during a phase in which it is still reversible may implicate in reductions in mortality and morbidity rates for those affected. Sufficient knowledge of the influence that environmental factors such as EV have on the development of T1D would make it possible to minimize the causes, thereby reducing the risks to which people are exposed.

The earlier patients can be diagnosed, and duly referred to appropriate clinical treatment, the better their quality of life will be and the morbidity and mortality rates will decrease. Nevertheless, there is still a need for greater knowledge of the many different agents involved and an improved understanding of the disease itself.

\section{COPYRIGHT}

(C) CEVAP 2012

\section{SUBMISSION STATUS}

Received: June 14, 2011.

Accepted: November 1, 2011.

Abstract published online: November 3, 2011.

Full paper published online: February 28, 2012.

\section{CONFLICTS OF INTEREST}

The authors declare no conflicts of interest.

\section{FINANCIAL SOURCE}

Fernando R. Spilki is a research fellow of The
National Council for Scientific and Technological Development (CNPq), Brazil.

\section{CORRESPONDENCE TO}

Rejane Giacomelli Tavares, Avenida Grécia, 1100/1805. Porto Alegre, RS, Brasil. Phone: +55 51 99710259. Email: tavares.rejane@gmail.com.

\section{REFERENCES}

1. World Health Organization. Definition and diagnosis of diabetes mellitus and intermediate hyperglycemia: a report of a WHO/IDF consultation. Geneva: World Health Organization; 2006.

2. Lotufo PA. Premature mortality from heart diseases in Brazil. A comparison with other countries. Arq Bras Cardiol. 1998;70(5):321-5.

3. Georg AE, Duncan BB, Toscano CM, Schmidt MI, Mengue S, Duarte C, et al. Análise econômica de programa para rastreamento do diabetes mellitus no Brasil. Rev Saúde Públ. 2005;39(3):452-60.

4. Wild S, Roglic G, Green A, Sicree R, King H. Global prevalence of diabetes: estimates for the year 2000 and projections for 2030. Diabetes Care. 2004;27(5):104753.

5. van der Werf N, Kroese FG, Rozing J, Hillebrands JL. Viral infections as potential triggers of type 1 diabetes. Diabetes Metab Res Rev. 2007;23(3):169-83.

6. American Diabetes Association [Internet]. Alexandria, VA: American Diabetes Association; [cited 2009 Sep 19]. Available from: http://www.diabetes.org/.

7. Devlin TM. Manual de bioquímica com correlações clínicas. 6th ed. São Paulo: Editora Edgard Blücher; 2007. 1216 p.

8. Jun HS, Khil LY, Yoon JW. Role of glutamic acid decarboxylase in the pathogenesis of type 1 diabetes. Cell Mol Life Sci. 2002;59(11):1892-901.

9. Eiselein L, Schwartz HJ, Rutledge JC. The challenge of type 1 diabetes mellitus. ILAR J. 2004;45(3):231-6.

10. DIAMOND Project Group. Incidence and trends of childhood type 1 diabetes worldwide 1990-1999. Diabet Med. 2006;23(8):857-66.

11. Craig ME, Howard NJ, Silink M, Chan A. The rising incidence of childhood type 1 diabetes in New South Wales, Australia. J Pediatr Endocrinol Metab. 2000;13(4):363-72.

12. Yang Z, Wang K, Li T, Sun W, Chang YF, Dorman JS, et al. Childhood diabetes in China. Enormous variation by place and ethnic group. Diabetes Care. 1998;21(4):525-9.

13. Yang Z, Long X, Shen J, Liu D, Dorman JS, Laporte RE, et al. Epidemics of type 1 diabetes in China. Pediatr Diabetes. 2005;6(3):122-8.

14. Ministério da Saúde. Portal da Saúde [Internet]. Brasília, DF: Ministério da Saúde Esplanada dos Ministérios; [cited 2009 Oct 16]. Available from: http://portal.saude.gov.br/portal/saude/visualizar_ texto.cfm?idtxt=29793\&janela $=1$.

15. Kyvik KO, Nystrom L, Gorus F, Songini M, Oestman J, Castell C, et al. The epidemiology of type 1 diabetes 
mellitus is not the same in young adults as in children. Diabetologia. 2004;47(3):377-84.

16. Pundziute-Lycka A, Dahlquist G, Nyström L, Arnqvist $\mathrm{H}$, Björk E, Blohmé G, et al. The incidence of type 1 diabetes has not increased but shifted to a younger age at diagnosis in the 0-34 years group in Sweden 1983 1998. Diabetologia. 2002;45(6):783-91.

17. Kolb H, Elliott RB. Increasing incidence of IDDM a consequence of improved hygiene? Diabetologia. 1994;37(7):729-31.

18. Kilkkinen A, Virtanen SM, Klaukka T, Kenward MG, Salkinoja-Salonen M, Gissler M, et al. Use of antimicrobials and risk of type 1 diabetes in a population-based mother-child cohort. Diabetologia. 2006;49(1):66-70.

19. Gibbon C, Smith T, Egger P, Betts P, Phillips D. Early infection and subsequent insulin dependent diabetes. Arch Dis Child. 1997;77(5):384-5.

20. Pundziute-Lycka A, Urbonaite B, Dahlquist G. Infections and risk of type 1 (insulin-dependent) diabetes mellitus in Lithuanian children. Diabetologia. 2000; 43(10):1229-34.

21. Thomsen M, Platz P, Andersen OO, Christy M, Lyngsooe J, Nerup J, et al. MLC typing in juvenile diabetes mellitus and idiopathic Addison's disease. Transplant Rev. 1975;22(1):125-47.

22. Horn GT, Bugawan TL, Long CM, Erlich HA. Allelic sequence variation of the HLA-DQ loci: relationship to serology and to insulin-dependent diabetes susceptibility. Proc Natl Acad Sci USA. 1988;85(16):6012-6.

23. Hober D, Sane F. Enteroviral pathogenesis of type 1 diabetes. Discov Med. 2010;10(51):151-60.

24. Warram JH, Krolewski AS, Kahn CR. Determinants of IDDM and perinatal mortality in children of diabetic mothers. Diabetes. 1988;37(10):1328-34.

25. Risch N. Assessing the role of HLA-linked and unlinked determinants of disease. Am J Hum Genet. 1987;40(1):1-14.

26. Barnett AH, Eff C, Leslie RD, Pyke DA. Diabetes in identical twins. A study of 200 pairs. Diabetologia. 1981;20(2):87-93.

27. Davies JL, Kawaguchi Y, Bennett ST, Copeman JB, Cordell HJ, Pritchard LE, et al. A genome-wide search for human type 1 diabetes susceptibility genes. Nature. 1994;371(6493):130-6.

28. Mehers KL, Gillespie KM. The genetic basis of type 1 diabetes. Br Med Bull. 2008;88(1):115-29.

29. Field LL. Genetic linkage and association studies of type 1 diabetes: challenges and rewards. Diabetologia. 2002;45(1):21-35.

30. Sanjeevi CB, DeWeese C, Landin-Olsson M, Kockum I, Dahlquist G, Lernmark A, et al. Analysis of critical residues of HLA-DQ6 molecules in insulin-dependent diabetes mellitus. Tissue Antigens. 1997;50(1):61-5.

31. Peng H, Hagopian W. Environmental factors in the development of type 1 diabetes. Rev Endocr Metab Disord. 2006;7(3):149-62.

32. Goldberg E, Krause I. Infection and type 1 diabetes mellitus - a two edged sword? Autoimmun Rev. 2009;8(8):682-6.
33. Chowdhury TA, Mijovic $\mathrm{CH}$, Barnett AH. The aetiology of type 1 diabetes. Baillieres Best Pract Res Clin Endocrinol Metab. 1999;13(2):181-95.

34. Gerstein HC. Cow's milk exposure and type 1 diabetes mellitus: a critical overview of the clinical literature. Diabetes Care. 1994;17(1):13-9.

35. Couper JJ, Steele C, Beresford S, Powell T, McCaul K, Pollard A, et al. Lack of association between duration of breast-feeding or introduction of cow's milk and development of islet autoimmunity. Diabetes. 1999;48(11):2145-9.

36. Akerblom HK, Knip M. Putative environmental factors in type 1 diabetes. Diabetes Metab Rev. 1998;14(1):3167.

37. Dahlquist GG, Blom LG, Persson LA, Sandström AI, Wall SG. Dietary factors and the risk of developing insulin dependent diabetes in childhood. Br Med J. 1990;300(6735):1302-6.

38. Greer RM, Rogers MA, Bowling FG, Buntain HM, Harris M, Leong GM, et al. Australian children and adolescents with type 1 diabetes have low vitamin D levels. Med J Aust. 2007;187(1):59-60.

39. Hyöty H, Taylor KW. The role of viruses in human diabetes. Diabetologia. 2002;45(10):1353-61.

40. Jun HS, Yoon JW. A new look at viruses in type 1 diabetes. Diabetes Metab Res Rev. 2003;19(1):8-31.

41. Parkkonen P, Hyöty H, Ilonen J, Reijonen H, YläHerttuala S, Leinikki P. Antibody reactivity to an Epstein-Barr virus BERF4-encoded epitope occurring also in Asp-57 region of HLA-DQ8 beta chain. Childhood Diabetes in Finland Study Group. Clin Exp Immunol. 1994;95(2):287-93.

42. Harris HF. A case of diabetes mellitus quickly following mumps. Boston Med Surg J. 1898;140(1):465-9.

43. Gamble DR. Relation of antecedent illness to development of diabetes in children. $\mathrm{Br}$ Med J. 1980;281(6233):99-101.

44. Helmke K, Otten A, Willems W. Islet cell antibodies in children with mumps infection. Lancet. 1980;2(8187):211-2.

45. Kremer HU. Juvenile diabetes as a sequel to mumps. Am J Med. 1947;3(2): 257.

46. Jaïdane H, Gharbi J, Lobert PE, Lucas B, Hiar R, M'hadheb MB, et al. Prolonged viral RNA detection in blood and lymphoid tissues from coxsackievirus B4 E2 orally-inoculated Swiss mice. Microbiol Immunol. 2006;50(12):971-4.

47. Hober D, Sauter P. Pathogenesis of type 1 diabetes mellitus: interplay between enterovirus and host. Nat Rev Endocrinol. 2010;6(5):279-89.

48. Gamble DR, Kinsley ML, FitzGerald MG, Bolton R, Taylor KW. Viral antibodies in diabetes mellitus. Br Med J. 1969;3(5671):627-30.

49. International Committee on Taxonomy of Viruses. Virus taxonomy: 2009 release [Internet]. [place unknown]: ICTV; [cited 2010 Jan 16]. Available from: http://www.ictvonline.org/virusTaxonomy. asp?version=2009.

50. Oliveira LHS. Virologia humana. Rio de Janeiro: Editora Cultura Médica; 1994. 341 p.

51. Nasri D, Bouslama L, Omar S, Saoudin H, Bourlet 
$\mathrm{T}$, Aouni M, et al. Typing of human enterovirus by partial sequencing of VP2. J Clin Microbiol. 2007;45 (8):2370-9.

52. Wu KX, Ng MM, Chu JJ. Developments towards antiviral therapies against enterovirus 71. Drug Discov Today. 2010;15(23-24):1041-51.

53. Roivainen M. Enteroviruses: new findings on the role of enteroviruses in type 1 diabetes. Int J Biochem Cell Biol. 2006;38(5-6):721-5.

54. Viskari H, Ludvigsson J, Uibo R, Salur L, Marciulionyte $\mathrm{D}$, Hermann $\mathrm{R}$, et al. Relationship between the incidence of type 1 diabetes and maternal enterovirus antibodies: time trends and geographical variation. Diabetologia. 2005;48(7): 1280-7.

55. Lee HK, Jeong YS. Comparison of total culturable virus assay and multiplex integrated cell culture-PCR for reliability of waterborne virus detection. Appl Environ Microbiol. 2004;70(6):3632-6.

56. Abbaszadega M. Advanced detection of viruses and protozoan parasites in water. Rev Biol Biotech. 2001;1(2):21-6.

57. Tebruegge $M$, Curtis N. Enterovirus infections in neonates. Semin Fetal Neonatal Med. 2009;14(4):2227.

58. Sawyer MH. Enterovirus infections: diagnosis and treatment. Pediatr Infect Dis J. 1999;18(12):1033-9.

59. Witso E, Palacios G, Cinek O, Stene LC, Grinde B, Janowitz D, et al. High prevalence of human enterovirus A infections in natural circulation of human enteroviruses. J Clin Microbiol. 2006;44(11):4095-100.

60. Figueiredo RM. PRP-SSOPs - Programa de redução de patógenos. Manual de procedimentos e desenvolvimento. São Paulo: Editora Manole; 1999. 166 p. 1 vol.

61. Lönnrot M, Salminen K, Knip M, Savola K, Kulmala $\mathrm{P}$, Leinikki $\mathrm{P}$, et al. Enterovirus RNA in serum is a risk factor for beta-cell autoimmunity and clinical type 1 diabetes: a prospective study. J Med Virol. 2000;61(2):214-20.

62. Graves PM, Norris JM, Pallansch MA, Gerling IC, Rewers $M$. The role of enteroviral infections in the development of IDDM: limitations of current approaches. Diabetes. 1997;46(2):161-8.

63. Sadeharju K, Lönnrot M, Kimpimäki T, Savola K, Erkkilä S, Kalliokoski T, et al. Enterovirus antibody levels during the first two years of life in prediabetic autoantibody-positive children. Diabetologia. 2001;44(7):818-23.

64. Velazquez A. Enteroviruses [Internet]. [place unknown]: WebMD LLC; 2006. [cited 2011 May 10]. Available from: <http://emidicine.medscape.com/ article/217146>.

65. Fong TT, Lipp EK. Enteric viruses of humans and animals in aquatic environments: health risks, detection, and potential water quality assessment tools. Microbiol Mol Biol Rev. 2005;69(2):357-71.

66. Ylipaasto P, Klingel K, Lindberg AM, Otonkoski T, Kandolf R, Hovi T, et al. Enterovirus infection in human pancreatic islet cells, islet tropism in vivo and receptor involvement in cultured islet beta cells. Diabetologia. 2004;47(2):225-39.
67. Richardson SJ, Willcox A, Bone AJ, Foulis AK, Morgan NG. The prevalence of enteroviral capsid protein vp1 immunostaining in pancreatic islets in human type 1 diabetes. Diabetologia. 2009;52(6):1143-51.

68. Akerblom HK, Vaarala O, Hyöty H, Ilonen J, Knip M. Environmental factors in the etiology of type 1 diabetes. Am J Med Genet. 2002;115(1):18-29.

69. Hänninen A, Jalkanen S, Salmi M, Toikkanen S, Nikolakaros G, Simell O. Macrophages, T cell receptor usage, and endothelial cell activation in the pancreas at the onset of insulin-dependent diabetes mellitus. J Clin Invest. 1992;90(5):1901-10.

70. Itoh N, Hanafusa T, Miyazaki A, Miyagawa J, Yamagata K, Yamamoto K, et al. Mononuclear cell infiltration and its relation to the expression of major histocompatibility complex antigens and adhesion molecules in pancreas biopsy specimens from newly diagnosed insulin-dependent diabetes mellitus patients. J Clin Invest. 1993;92(5):2313-22.

71. Greiner DL, Rossini AA, Mordes JP. Translating data from animal models into methods for preventing human autoimmune diabetes mellitus: caveat emptor and primum non nocere. Clin Immunol. 2001;100(2):134-43.

72. Achenbach P, Lampasona V, Landherr U, Koczwara $\mathrm{K}$, Krause S, Grallert H, et al. Autoantibodies to zinc transporter 8 and SLC30A8 genotype stratify type 1 diabetes risk. Diabetologia. 2009;52(9):1881-8.

73. Erlander MG, Tillakaratne NJ, Feldblum S, Patel $\mathrm{N}$, Tobin AJ. Two genes encode distinct glutamate decarboxylases. Neuron. 1991;7(1):91-100.

74. Erdö SL, Wolff JR. Gamma-aminobutyric acid outside the mammalian brain. J Neurochem. 1990;54(2):36372.

75. Tillakaratne NJ, Erlander MG, Collard MW, Greif KF, Tobin AJ. Glutamate decarboxylases in nonneural cells of rat testis and oviduct: differential expression of $\mathrm{GAD}_{65}$ and $\mathrm{GAD}_{67}$. J Neurochem. 1992;58(2):618-27.

76. Faulkner-Jones BE, Cram DS, Kun J, Harrison LC. Localization and quantitation of expression of two glutamate decarboxylase genes in pancreatic betacells and other peripheral tissues of mouse and rat. Endocrinology. 1993;133(6):2962-72.

77. Petersen JS, Russel S, Marshall MO, Kofod H, Buschard $\mathrm{K}$, Cambon N, et al. Differential expression of glutamic acid decarboxylase in rat and human islets. Diabetes. 1993;42(3):484-95.

78. Castaño L, Eisenbarth GS. Type-I diabetes: a chronic autoimmune disease of human, mouse, and rat. Annu Rev Immunol. 1990;8(1):647-79.

79. Gupta S, Koirala J, Khardori R, Khardori N. Infections in diabetes mellitus and hyperglycemia. Infect Dis Clin North Am. 2007;21(3):617-38.

80. Pankewycz OG, Guan JX, Benedict JF. Cytokines as mediators of autoimmune diabetes and diabetic complications. Endocr Rev. 1995;16(2):164-76.

81. Faust A, Kleeman R, Rothe H, Knob H. Role of macrophages and cytokines in $\beta$ cell death. In: Shafrir E, editor. Lessons from animal diabetes VI. Boston: Birkhäuser; 1996. p. 47-56.

82. Corbett JA, McDaniel ML. Does nitric oxide mediate 
autoimmune destruction of beta-cells? Possible therapeutic interventions in IDDM. Diabetes. 1992;41(8):897-903.

83. Toms GC, Baker P, Boucher BJ. The production of immunoreactive alpha- and gamma-interferon by circulating mononuclear cells in type 1 diabetes. Diabet Med. 1991;8(6):547-50.

84. Kukreja A, Maclaren NK. Current cases in which epitope mimicry is considered as a component cause of autoimmune disease: immune-mediated (type 1) diabetes. Cell Mol Life Sci. 2000;57(4):534-41.

85. Wolf E, Spencer KM, Cudworth AG. The genetic susceptibility to type 1 (insulin-dependent) diabetes: analysis of the HLA-DR association. Diabetologia. 1983;24(4):224-30.

86. Thomson G, Robinson WP, Kuhner MK, Joe S, MacDonald MJ, Gottschall JL, et al. Genetic heterogeneity, models of inheritance, and risk estimates for a joint study of Caucasians with insulin-dependent diabetes mellitus. Am J Hum Genet. 1988;43(6):799816.

87. Sperling MA. Type 1 diabetes: etiology and treatment. $1^{\text {st }}$ ed. New Jersey: Humana Press Inc; 2003. 591 p.

88. Thomas HE, McKenzie MD, Angstetra E, Campbell PD, Kay TW. Beta cell apoptosis in diabetes. Apoptosis. 2009;14(12):1389-404.

89. Yoon JW, McClintock PR, Onodera T, Notkins AL. Virus-induced diabetes mellitus. XVIII. Inhibition by a nondiabetogenic variant of encephalomyocarditis virus. J Exp Med. 1980;152(4):878-92.

90. Clements GB, Galbraith DN, Taylor KW. Coxsackie $B$ virus infection and onset of childhood diabetes. Lancet. 1995;346(8969):221-3.

91. Andréoletti L, Hober D, Hober-Vandenberghe C, Belaich S, Vantyghem MC, Lefebvre J, et al. Detection of coxsackie B virus RNA sequences in whole blood samples from adult patients at the onset of type I diabetes mellitus. J Med Virol. 1997;52(2):121-7.

92. Helfand RF, Gary HE Jr, Freeman CY, Anderson LJ, Pallansch MA. Serological evidence of an association between enteroviruses and the onset of type 1 diabetes mellitus. Pittsburg Diabetes Research Group. J Infect Dis. 1995; 172(5):1206-11.

93. Nairn C, Galbraith DN, Taylor KW, Clements GB. Enterovirus variants in the serum of children at the onset of type 1 diabetes mellitus. Diabet Med. 1999;16(6):509-13.

94. Lönnrot M, Korpela K, Knip M, Ilonen J, Simell O, Korhonen S, et al. Enterovirus infection as a risk factor for beta-cell autoimmunity in a prospectively observed birth cohort: the Finnish Diabetes Prediction and Prevention Study. Diabetes. 2000;49(8):1314-8.

95. Craig ME, Howard NJ, Silink M, Rawlinson WD. Reduced frequency of HLA DRB $1^{\star} 03-\mathrm{DQB} 1^{\star} 02$ in children with type 1 diabetes associated with enterovirus RNA. J Infect Dis. 2003;187(10):1562-70.

96. Sarmiento L, Cabrera-Rode E, Lekuleni L, Cuba I, Molina G, Fonseca M, et al. Occurence of enterovirus RNA in serum of children with newly diagnosed type 1 diabetes and islet cell autoantibody-positive subjects in a population with a low incidence of type 1 diabetes.
Autoimmunity. 2007;40(7):540-5.

97. Oikarinen M, Tauriainen S, Honkanen T, Oikarinen S, Vuori K, Kaukinen K, et al. Detection of enteroviruses in the intestine of type 1 diabetic patients. Clin Exp Immunol. 2008;151(1):71-5.

98. Hyöty $H$, Hiltunen $M$, Knip $M$, Laakkonen $M$, Vähäsalo $\mathrm{P}$, Karjalainen J, et al. A prospective study of the role of coxsackie $\mathrm{B}$ and other enterovirus infections in the pathogenesis of IDDM. Childhood Diabetes in Finland (DiMe) Study Group. Diabetes. 1995;44(6):652-7.

99. Hiltunen M, Hyöty H, Knip M, Illonen J, Reijonen $\mathrm{H}$, Väkärdo $\mathrm{P}$, et al. Islet cell antibody seroconversion in children is temporally associated with enterovirus infection. Childhood Diabetes in Finland (DiMe) Study Group. J Infect Dis. 1997;175(3):554-60.

100. Hadden DR, Connolly JH, Montgomery DA, Weaver JA. Coxsackie B virus diabetes. Br Med J. 1972;4(5842):729.

101. Tuvemo T, Dahlquist G, Frisk G, Blom L, Friman G, Landin-Olsson M, et al. The Swedish childhood diabetes study III: IgM against coxsackie B viruses in newly diagnosed type 1 (insulin-dependent) diabetic children - no evidence of increased antibody frequency. Diabetologia. 1989;32(10):745-7.

102. Graves PM, Rotbart HA, Nix WA, Pallansch MA, Erlich HA, Norris JM, et al. Prospective study of enteroviral infections and development of beta-cell autoimmunity. Diabetes autoimmunity study in the young (DAISY). Diabetes Res Clin Pract. 2003;59(1):51-61.

103. Dahlquist GG, Ivarsson SA, Lindberg B, Forsgren M. Maternal enteroviral infection during pregnancy as a risk factor for childhood IDDM. A population-based case-control study. Diabetes. 1995;44(4):408-13.

104. Dahlquist GG, Frisk G, Ivarsson SA, Svanberg L, Forsgen M, Diderholm $\mathrm{H}$. Indications that maternal coxsackie $\mathrm{B}$ infection during pregnancy is a risk factor for childhood-onset IDDM. Diabetologia. 1995;38(11):1371-3.

105. Elfving M, Svensson J, Oikarinen S, Jonsson B, Olofsson P, Sundkvist G, et al. Maternal enterovirus infection during pregnancy as a risk factor in offspring diagnosed with type 1 diabetes between 15 and 30 years of age. Exp Diabetes Res. 2008;2008(1):271958.

106. Frisk G, Nilsson F, Tuvemo T, Friman G, Diderholm $\mathrm{H}$. The possible role of coxsackie $\mathrm{A}$ and echo viruses in the pathogenesis of type 1 diabetes mellitus studied by IgM analysis. J Infect. 1992;24(1):13-22.

107. Díaz-Horta O, Bello M, Cabrera-Rode E, Suárez J, Más P, García I, et al. Echovirus 4 and type 1 diabetes mellitus. Autoimmunity. 2001;34(4):275-81.

108. Dahlquist GG, Forsberg J, Hagenfeldt L, Boman J, Juto P. Increased prevalence of enteroviral RNA in blood spots from newborn children who later developed type 1 diabetes: a population-based case-control study. Diabetes Care. 2004;27(1):285-6. 